\title{
Seleksi Primer LCO - HCO, Primer bird-f1 - HCO Dan Primer bch - bcl Untuk Amplifikasi Gen COI DNA Mitokondria Itik Magelang (Anas javanica)
}

\author{
Sonny Abdi Setiyawan, Anto Budiharjo dan Hermin Pancasakti Kusumaningrum \\ Jurusan Biologi, Fakultas Sains dan Matematika, Undip \\ Jl. Prof Soedharto, Tembalang, Semarang - 50275 \\ Telepon (024) 7474754; Fax. (024) 76480690 \\ Email: sonny_abdi@yahoo.com
}

\begin{abstract}
Abstrak
Itik Magelang merupakan itik liar asli Indonesia.Keunggulan itik Magelang dibanding itik lokal lainnya selain kemampuan hidup di dataran tinggi dan dataran rendah juga produksi telur dan produksi dagingnya tinggi. Sampai saat ini karakterisasi genetik itik Magelang untuk mengetahui informasi lengkap mengenai genetiknya belum pernah dilakukan. Tujuan penelitian adalah melakukan seleksi primer untuk melacak gen COI DNA mitokondria itik Magelang menggunakan primer LCO-HCO, primer bird-f1 - HCO, dan primer bch-bcl. Metode penelitian dilakukan dengan isolasi DNA itik Magelang. Selanjutnya dilakukan seleksi primer secara in silico untuk melacak kesesuaian primer dengan gen COI DNA mitokondria itik dari dataGenBankmenggunakan program ClustalX, Genedoc dan FastPCR. Seleksi primer selanjutnya dilakukan dengan teknik PCR untuk amplifikasi gen COI DNA mitokondria itik Magelang menggunakan ketiga pasang primer. Hasil analisishomologi primer memperlihatkan hanya sebagian dari ketiga primer yanghomolog pada gen target. Hasil amplifikasi menggunakan PCR dengan primer LCO-HCO diduga menghasilkan primer dimer. Primer birdf1 - HCO dan primer bch-bcltidak memunculkan pita hasil amplifikasi daerah gen COI DNA mitokondria itik Magelang.
\end{abstract}

Kata kunci : itik Magelang, gen COI , DNA mitokondria, primer

\begin{abstract}
Magelang duck is a wild type of local duck from Indonesia. The advantagesof Magelangduckcompare tootherlocalduck from Indonesiaareabilityto livein the highlandsandlowlands and high production of egg and meat. Geneticcharacterization of Magelangduck still not available until now.The aim of the research is selectprimers forampliflying COIgeneof mitochondrialDNAof MagelangduckusingLCO-HCO, bird-f1 -HCO, andbcl-bch primers. The research methodwas DNAisolationfrom Magelangduck. Followed by, selection of primer in silicoto find homologywithin COIsequenceusing ClustalX, Genedoc, and FastPCR programs. Amplification of COIgenewas performedusing PCRwith all primerpairs. Result showed partial homology with all primer in COI sequence. TheamplificationusingtheLCO-HCO primer produced primerdimer.Primerbirdf1-HCOand bch-bcl primers showed no amplification.
\end{abstract}

Key words: Magelang duck, COI gene, mitochondrial DNA, primer

\section{PENDAHULUAN}

Penurunan populasi ternak itik di Indonesia terjadi dari tahun ke tahun.Faktor penyebab penurunan ternak itik antara lain adalah, tekanan ekonomi, tidak ada peningkatan mutu genetik yang dikarenakan para peternak itik secara umum masih minim pengetahuan dan penggantian rumpun ternak dan persilangan yang tidak terarah dengan rumpun ternak eksotik(Subandriyo, 2006).Itik Magelang merupakan itik asli Indonesiadan merupakan sumber daya alam hayati yang sangat potensial untuk dikembangkan dalam rangka pemenuhan kebutuhan pangan.Itik Magelang termasuk dalam golongan itik penghasil telur dan daging yang produksinya tinggi (Dinas Peternakan dan Kesehatan Hewan, 2010). Kemampuan hidup itik Magelang di dataran tinggi dan dataran rendah juga menyebabkan ketahanan tubuhnya lebih baik dibanding itik lain.Karakteristik khas itik Magelang masih terbatas pada fenotip belum 
sampai pada tahap karakter genetik. Karakterisasi genetik itik merupakan suatu upaya awal dalam pelestarian itik lokal Indonesia.Variasi antar individu dapat dikarakterisasi secara genetik dengan teknik PCR menggunakan sepasang primer. Permasalahan yang timbul adalah belum adanya primer spesifik untuk amplifikasi gen COI DNA mitokondria itik Magelang.

Berdasarkan hal tersebut, penelitian ini bertujuanmemperoleh primer yang bisa digunakan untuk amplifikasi gen COI DNA mitokondria itik Magelang.

\section{Materi dan Metode Bahan Penelitian}

Bahan yang digunakan dalam penelitian ini antara lain adalahitik Magelang umur 5 bulan, es batu, bufer digesti, enzim lisozim, sodium dodesil sulfat (SDS), fenol kloroform, sodium asetat 3M $\mathrm{pH} 5.2$, etanol $100 \%$, etanol $70 \%$, bufer Tris Etilen Diamintetraasetat (EDTA), bufer TE pH 8, akuades, agarosa, bufer Tris, asam asetat glasial dan EDTA(TAE), loading dye, good view, Ethidium Bromida (EtBr), primer LCO-HCO koleksi laboratorium genetika, primer bird-f1 (Bondoc, 2012), primer bch-bcl atas kebaikan Dr. rer. nat. Anto Budiharjo, S.Si. M.Biotech, Ampli Taq (bufer PCR 10x, dNTPs, TAQ poly) $=12,5 \mathrm{~L}$ dan $\operatorname{ddH}_{2} \mathrm{O}$.

\section{Ekstraksi DNA itik Magelang}

Ekstraksi DNA itik Magelang dilakukan menggunakan metode Fenol-Kloroform modifikasi Aussubel et al., (1995).

Sampel ditumbuk dengan mortar pastel kemudian ditambahkan bufer digesti sebanyak 6 $\mathrm{ml}$ untuk $1 \mathrm{~g}$ sampel.Setelah itu ditambahkan enzim lisozim $10 \mathrm{mg} / \mathrm{ml}$ sebanyak 10 L.Suspensi kemudian diinkubasi pada suhu $37^{\circ} \mathrm{C}$ selama 1 jam dalam kondisi diapungkan. Suspensi kemudian ditambahkan SDS 10\% sebanyak $1 \mathrm{ml}$ untuk $1 \mathrm{~g}$ sampel.Suspensi dihomogenkan dan di inkubasi pada suhu $50^{\circ} \mathrm{C}$ selama 12 jam, setiap 30 menit sekali dilakukan homogenisasi.Suspensi disentrifugasi pada kecepatan 10.000 rpm selama 5 menit.Tahap selanjutnya supernatan diambil dan ditambah dengan fenol : kloroform dengan perbandingan 1:1.Suspensi lalu ditambah dengan sodium asetat $3 \mathrm{M}$ pH 5,2 sebanyak 1/10 volume, fasa atas yang di ambil dan kemudian dihomogenkan. Sampel ditambah dengan etanol $100 \%$ sebanyak 2 volume sampel kemudian dihomogenkan.Pelet yang terbentuk ditambahkan etanol $70 \%$ sebanyak $500 \quad \mathrm{~L}$ dan kemudian disentrifugasi kembali.Pelet akhir yang terbentuk diambil dan dikeringanginkan selama 24 jam. Pelet ditambahkan bufer TE pH 7,6 sebanyak 10$20 \mathrm{~L}$ dan kemudian disimpan pada freezer.

\section{Elektroforesis}

Sampel DNA yang didapat di running dengan proses elektroforesis. Running DNA dilakukan pada gel agarosa $2 \%$.Sampel DNA di ambil sebanyak 5 L dan dicampur dengan loading dye.Kemudian sampel dimasukkan kedalam sumur cetakan pada gel agarosa.Tangki elektroforesis dihubungkan dengan arus listrik dan diatur arusnya sebesar 100 Volt selama 10-15 menit.Pengamatan dilakukan di bawah sinar UV dan didokumentasikan.

\section{Amplifikasi DNA dengan PCR}

Proses PCR untuk memperbanyak gen COI dari DNA mitokondria yang diperoleh.Primer yang digunakan adalah primer $\mathrm{HCO}$ dan primer birdf1.Kondisi PCR untuk amplifikasi gen COI: denaturasi awal pada suhu $94^{\circ} \mathrm{C}$ selama 5 menit, denaturasi pada suhu $94^{\circ} \mathrm{C}$ selama 40 detik, annealing pada suhu $58^{\circ} \mathrm{C}$ selama 40 detik, elongasi pada suhu $72^{\circ} \mathrm{C}$ selama 1 menit, elongasi akhir pada suhu $72^{\circ} \mathrm{C}$ selama 7 menit, suhu akhir pada suhu $4^{\circ} \mathrm{C}$, siklus diatur sebanyak $30 \mathrm{X}$.

\section{Pelacakan gen COI DNA mitokondria}

Sekuen DNA mitokondria itik pada GenBank dipakai sebagai sumber data.Sekuen ini kemudian dianalisis menggunakan program BLAST untuk menentukan daerah terkonservasi dan konfirmasi sekuen nukleotidanya. Pelacakan gen COI dilakukan dengan mencari urutan basa dari gen COI beberapa itik yang berkerabat dengan itik Magelang. Sekuen disejajarkan dengan program komputer Clustal $X$, Genedoc dan FastPCR. 


\section{Penyejajaran primer pada urutan basa DNA itik Magelang}

Penyejajaran dilakukan dengan beberapa spesies itik hasil penelusuran dengan ClustalX untuk selanjutnya dibaca hasilnya menggunakan program Genedoc. Pelacakan ini dilakukan dengan primer LCO - HCO, primer bird-f1 - HCO, dan primer bch - bcl.

Tabel 1.Primer yang digunakan untuk pelacakan gen COI

\begin{tabular}{|c|c|}
\hline $\begin{array}{c}\text { Prim } \\
\text { er }\end{array}$ & $\begin{array}{l}\text { Urutan Basa Primer } \\
\quad\left(5^{\prime} \mathrm{ke} \mathrm{3}\right)\end{array}$ \\
\hline LCO & 5'- ggtcaacaaatcataaagatattgg -3' \\
\hline $\begin{array}{c}\mathrm{HC} \\
\mathrm{O}\end{array}$ & 5 ' - taaacttcagggtgaccaaaaaatca -3 ' \\
\hline $\begin{array}{c}\text { birdf } \\
1\end{array}$ & 5 '- ttctccaaccacaaagacattggcac -3 ' \\
\hline bch & 5'- taaacttcagggtgaccaaaaaatca -3 , \\
\hline bcl & 5'- tcaacyaatcayaaagatatyggcac -3 , \\
\hline
\end{tabular}

\section{Hasil dan Pembahasan}

Isolasi dan ekstraksi DNA itik Magelang (Anasjavanica) dilakukan dengan cara mengambil sebagian otot dari bagian sayap itik Magelang.Hal ini dilakukan sesuai dengan metode optimasi perolehan DNA kerang simping (Amusium pleuronectes) oleh Sudjito (2012), yang memperoleh konsentrasi DNA sebesar 4500ng/ L.Hasil penelitian kali ini mendapatkan konsentrasi DNA sebesar $8130 \mathrm{ng} / \mathrm{L}$, nilai ini lebih besar dibanding dengan penelitian Wibowo (2012) pada itik Tegal (Anas domesticus) yang memperoleh konsentrasi 2610 ng/ L.Nilai kemurnian yang diperolehsebesar 1,09masih dibawah nilai kemurnian yang baik.Tingkat kemurnian DNA yang baik pada panjang gelombang $\lambda_{260 / 280}$ yaitu sebesar 1,8-2,0 (Sambrook et al., 1989).
Tabel 2. Konsentrasi dan kemurnian DNA

\begin{tabular}{cccl}
\hline Sampel & Ulangan & $\begin{array}{c}\text { Konsentrasi } \\
\text { DNA } \\
(\mathrm{ng} / \mathrm{L})\end{array}$ & $\begin{array}{l}\text { Kemurnian } \\
\text { DNA } \\
\left(\lambda_{260 / 280}\right)\end{array}$ \\
\hline DNA Itik & 1 & 8100 & 1,08 \\
Magelang & 2 & 8130 & 1,09 \\
& 3 & 8130 & 1,09 \\
\hline
\end{tabular}

Nilai kemurnian DNA yang masih dibawah dari standar nilai kemurnian dikarenakan masih terdapat kontaminan pada DNA dari itik Magelang seperti protein yang belum terpresipitasi dengan -sempurna. Hal ini terjadi karena proses dari purifikasi DNA yang masih mengandung kontaminan protein. Sedangkan untuk konsentrasi DNA yang di dapat nilainya sudah cukup baik yang memperlihatkan bahwa DNA dapat tervisualisasi dibawah sinar UV dengan baik.

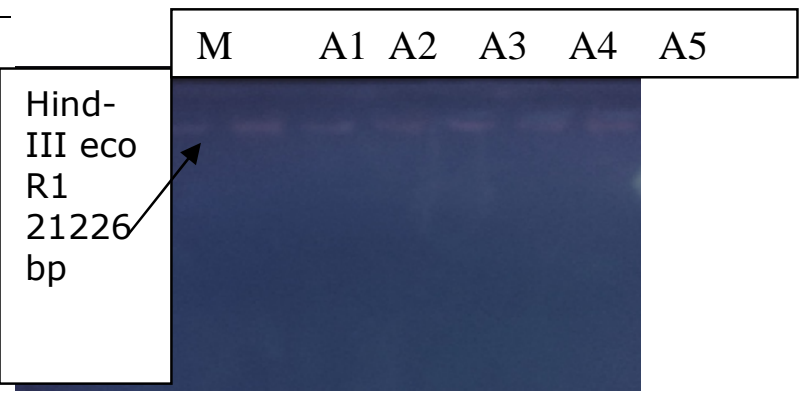

Gambar 1. Visualisasi DNA itik Magelang Ket: $\mathrm{M}=$ marka DNA Hind-III eco R1, A1-A7= DNA itik Magelang

Kenampakan pita tunggal DNA yang memancar pada gel agarosa dibawah sinar UV (Gambar 1) menunjukkan bahwa hasil proses isolasi dan ekstraksi DNA itik Magelang telah berhasil memperoleh DNA itik Magelang. DNA hasil isolasi yang diperoleh jumlahnya memenuhi syarat untuk dapat digunakan pada tahapan amplifikasi yang minimal mempunyai konsentrasi sebanyak 25-50 ng/ L (Sulistyaningsih, 2008).

Pelacakan dan analisis gen COI DNA mitokondria itik Magelang dengan kesesuaian primer LCO dan HCO telah dilakukan secara in silico menggunakan program ClustalX pada beberapa anggota genus Anas. 
Hasil visualisasi DNA itik Magelang
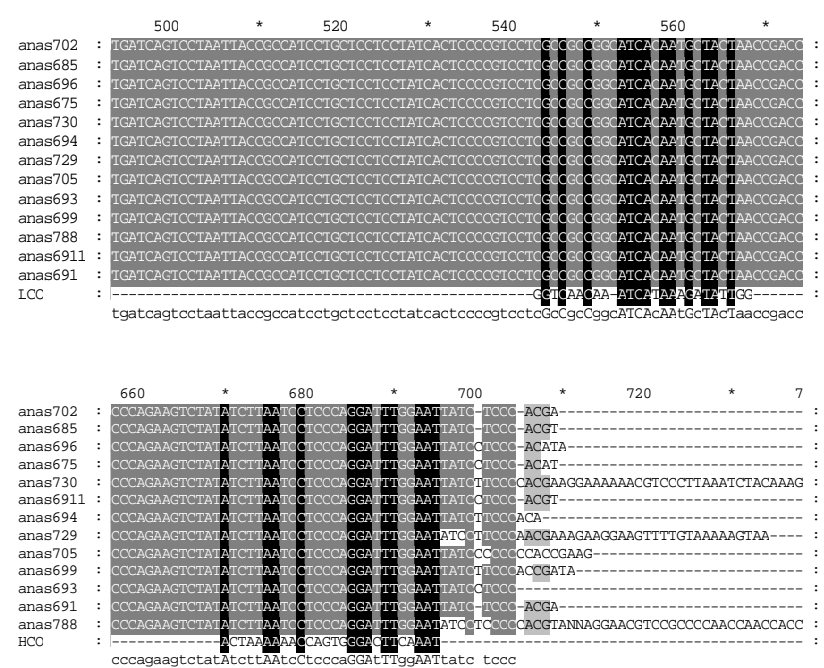

Gambar 2. Penyejajaran primer LCO-HCO dengan sekuen basa genus Anas

Homologi primer LCO-HCO apabila digunakan untuk mengamplifikasi daerah gen COI akan memperoleh fragmen sepanjang sekitar 117 bp. Pelacakan gen dengan menggunakan primer LCO-HCO diatas memperlihatkan bahwa primer LCO-HCO bila digunakan untuk amplifikasi DNA itik Magelang masih banyak yang tidak homolog pada pasangan DNA target.

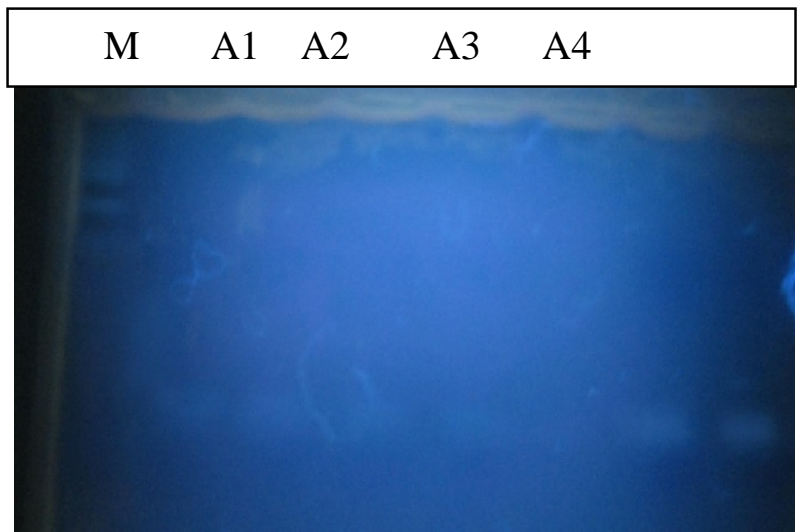

Gambar 3. Visualisasi DNA itik Magelang hasil amplifikasi menggunakan primer LCO$\mathrm{HCO}$

Ket: $\quad$ M=marka, A5\&A6=DNA itik Magelang (A1\&A2= itik Tegal, A3\&A4=DNA itik Semarang, milik peneliti lain). menggunakan primer LCO-HCO yang belum jelas 599 592 tara pita DNA atau primer dimer yang terbentuk ${ }_{55}^{5}$ pada gel agarosa kemudian dilakukan pengujian ${ }_{55}^{56}$ lang dengan mengirim sampel DNA hasil ${ }_{5 a}^{56}$ amplifikasi ke Laboratorium Genetika Science

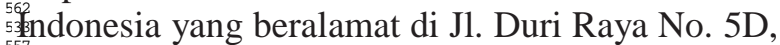
55 Fakarta Barat 11510, Indonesia.

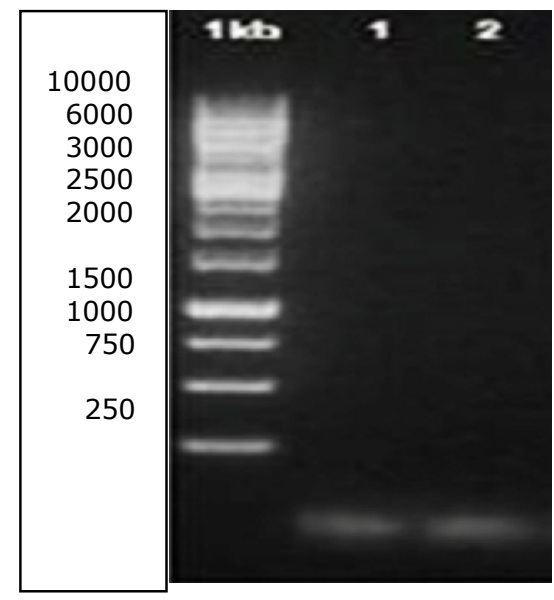

Gambar 5.Visualisasi DNA itik Magelang hasil amplifikasimenggunakan primer LCOHCO pada Laboratorium Genetika Science Indonesia.

Ket: 1\&2: Primer dimer

Hasil visualisasi dari Laboratorium Genetika Science Indonesia memperlihatkan pita DNA yang terbentuk terlalu tipis pada gel agarosanya.Pita yang terbentuk pada Gambar 5.juga memperlihatkan pita tersebut terlihat terlalu jauh di bawah marka yang dipakai. Hal ini menunjukkan bahwa pita yang di dapat hasil amplifikasi tersebut berpeluang besar suatu primer dimer.Primer dimer merupakan suatu tanda dimana terjadi kesalahan saat amplifikasi yang ditandai dengan terbentuknya suatu pita DNA di bawah panjang marker yang dipakai (Yuwono, 2009).

Pelacakan gen COI DNA mitokondria itik Magelang juga dilakukan dengan penyejajaran basa dengan primer degeneratif yang bekerja pada lokus gen COI DNA mitokondria. Primer degeneratif merupakan primer yang mempunyai salah satu susunan basa yang dapat dibaca ganda. 
Primer yang digunakan adalah primer forward bch dan primer reversebcl.

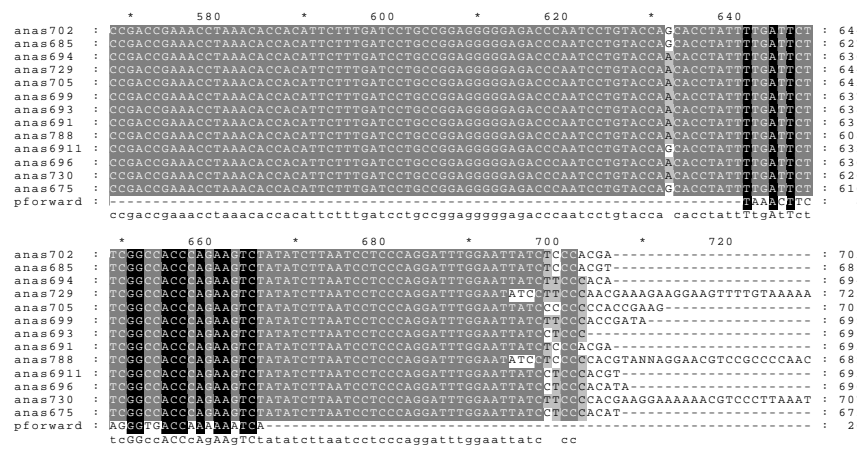

Gambar 6.Penyejajaran primer forward bch dengan sekuen basa genus Anas dipusat Data GenBank.

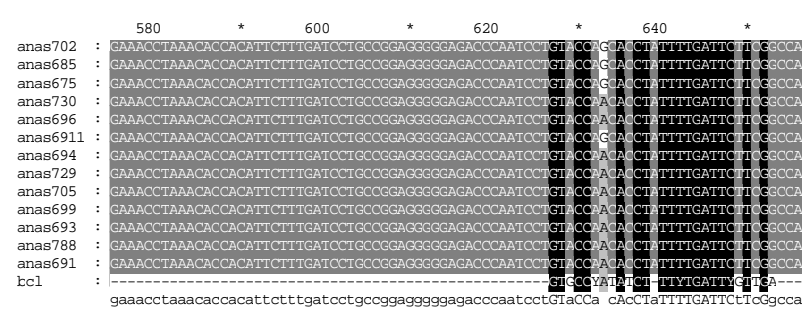

Gambar 7. Penyejajaran primer reverse bcl dengan sekuen basa genus Anaspada pusat data GenBank.

Prosentase $\mathrm{G}+\mathrm{C}$ dalam primer bch sebesar $34,2 \%$ dan primer bcl sebesar 38\% masih di bawah nilai prosentase yang baik sebesar $50-60 \%$ yang merupakan syarat keberhasilan amplifikasi PCR. Homologi primer forward bch juga kurang sempurna pada sekuen DNA target. Pada primer bcl mempunyai 5 urutan terakhir basanya yang mengandung basa $\mathrm{G}$ dan $\mathrm{C}$ sebanyak 3 basa secara berurutan, hal ini juga dapat berpeluang terjadinya primer dimer. Urutan basa primer yang mengandung basa $\mathrm{G}$ dan $\mathrm{C}$ ( $\mathrm{GC}$ clamp) pada 3 urutan terakhir basa primernya dapat mengakibatkan primer dimer(Yuwono, 2009).

Seleksi primer lainuntuk pelacakan gen COI DNA mitokondria itik Magelang menggunakan primer bird-f1 didapat dari penelitian Bondoc(2012). Sebelumnya penelitian menggunakan gen COI DNA mitokondria itik pada GenBank hanya dilakukan oleh Ahanthem \&
Ghosh (2011) pada Anas platyrhynchos. Primer bird-f1 hanya homolog beberapa sekuen basa pada DNA target (Gambar 8.). Prosentase basa $\mathrm{G}+\mathrm{C}$ pada primer bird-f1 sebesar $48 \%$, dimana prosentase ini sudah mendekati syarat keberhasilan proses amplifikasi PCR.

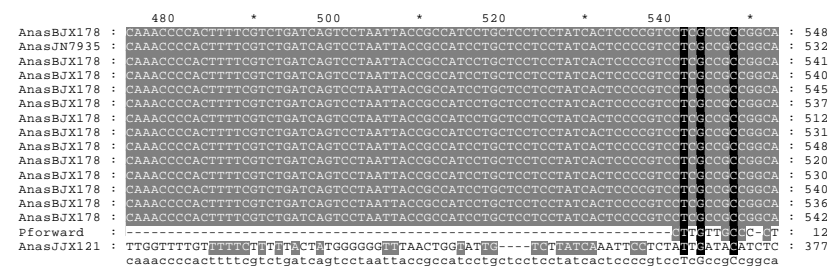

Gambar 8. Penyejajaran primer bird-f1dengan sekuen basa gen COI genus Anasdari pusat data GenBank.

Data mengenai primer yang didapat diatas 651 6 memperlihatkan bahwa ketiga pasang primer yang ${ }_{6}^{623}$ digunakan untuk pelacakan gen COI DNA 6ำnitokondria itik masih banyak yang kurang ${ }^{667}$ 6momolog pada sekuen basa DNA target. Hal ini ${ }_{6}^{64}$ dikarenakan sekuen basa dari beberapa itik yang 'Berada di pusat data GenBank masih sangat bervariasi, sehingga daerah yang homolog dengan primer juga masih sangat variatif.

Pita DNA itik Magelang hasil amplifikasi menggunakan primer bird-f1 - HCO tidak terlihat dikarenakan karena primer yang digunakan tidak dapat homolog secara sempurna pada sekuen basa DNA itik Magelang.Primer forward bird-f1 dan reverse $\mathrm{HCO}$ hanya mendapatkan fragmen gen COI sepanjang sekitar 127 bp saja, dapat dikatakan proses amplifikasi yang diharapkan belum dapat memperoleh pita yang sesuai dengan ukuran gen COI DNA mitokondria. Fragmen gen COI yang didapat tersebut pada saat dilakukan visualisasi di bawah sinar UV (Gambar 9) bila mendapatkan pita DNA pasti berada jauh di bawah marka yang dipakai dan bisa diduga juga sebagai primer dimer. 


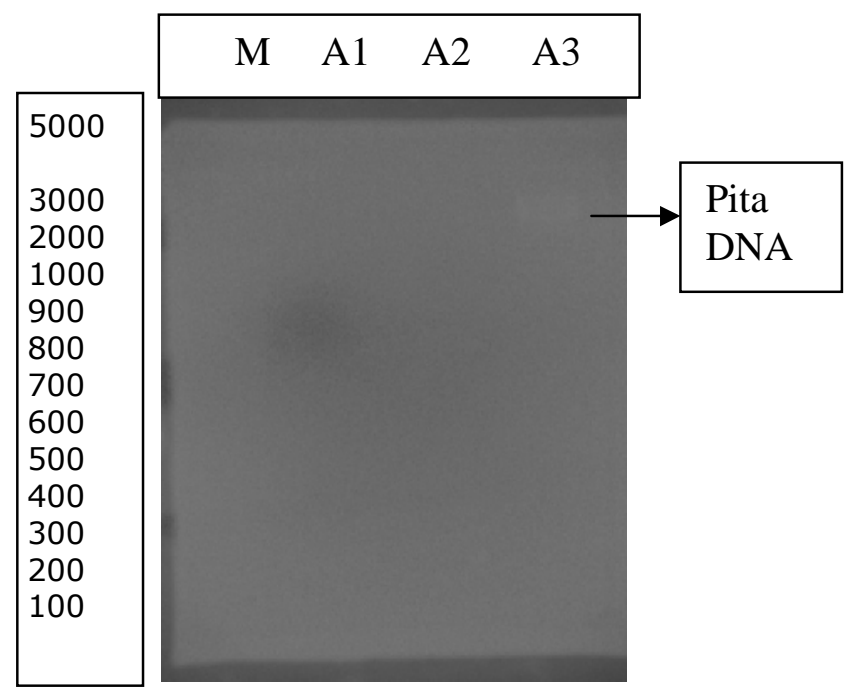

Gambar 9.Visualisasi DNA itik Magelang (Ket. $\mathrm{M}=$ DNA marka 100 bp, A1= DNA itik Magelang, A2= kontrol, A3= DNA marka.

Amplifikasi gen COI pada DNA itik menggunakan primer biasanya akan menghasilkan fragmen berukuran antara $400-600 \mathrm{bp}$ (Bondoc, 2012). Penelitian yang telah dilakukan ini memperlihatkan bahwa amplifikasi menggunakanprimer HCO-LCO, primer birdf1 HCO dan primer bch-bcl belum dapat menghasilkan fragmen yang sesuai dengan ukuran target gen COI DNA mitokondria. Dengan demikian ketiga primer tidak dapat digunakan untuk mengamplifikasi gen COI DNA mitokondria pada itik Magelang.

Desain ulang primer sangat diperlukan untuk solusi sebagai upaya untuk mendapatkan primer yang mampu digunakan untuk amplifikasi DNA itik Magelang. Desain ulang primer ini menggunakan bantuan program pick primer pada pusat data GenBank. Primer yang didapat dari sekuen basa dari Anas platyrhynchos untuk panjang basa diatas 600 bp dengan suhu leleh primer sekitar $58{ }^{\circ} \mathrm{C}$ pada pusat data GenBank memperoleh hasil urutan basa untuk primer forward adalah 5'- ttgttgcccctccacaaaga -3' dan untuk primer reverse adalah 5'cctccggcaggatcaaagaa -3 '.

Homologi basa primer dengan urutan basa DNA target apabila digunakan untuk mengamplifikasi daerah gen COI akan mendapatkan fragmen sepanjang sekitar $570 \mathrm{bp}$. Desain primer yang didapat dari GenBank ini mampu menghasilkan fragmen gen COI yang memenuhi syarat untuk dilakukan tahapan sekuensing guna mengetahui informasi genetik itik Magelang pada penelitian selanjutnya. Pengujian spesifitas desain primer ini juga digunakan program FastPCR seperti tampak pada Gambar 10.

\section{$>$ anas693}

acagcttaactaacTTGTTGCCCCTCCACAAA GAcgttggggtataacttggctatccatggcccetagagggcgacg actcatttataacgtgatcgtcaccgctcacgcctatctaataatcttcttc atggtaatgcccatcataattggagagttcggcagctgattggtccccc tgataatcggtgcccccgacatagcattcccacgaataaacaacataa gcatctgactcctcccaccatcattcctcettatactcgectcatccactg taaaagctggcgctggtacgggttgaaccgtatacccacctctagcag gcaacctagcccacgccggagcctcagtggacctggctatcttctcac ttcacetggetggtgtctcctccatcctcggagccattaacttcattacca cagccatcaacataaaacceccegcactctcacaataccaaacccca cttttcgtctgatcagtcctaattaccgecatcctgetcctcctatcactcc ccgtcctcgccgccggcatcacaatgctactaaccgaccgaaaccta aacaccacaTTCTTTGATCCTGCCGGAGGgggaga cccaatcctgtaccaacacctattttgattcttcggccacccagaagtct atatcttaatcctcccaggatttggaattatcctccc

Gambar 10. Pengujian spesifitas desain primer menggunakan FastPCR pada sekuen basa genus Anas

Ket : homologi primer berwarna biru

Primer forward - reverse akan homolog pada sekuen basa itik pada daerah yang konserve dan mendapatkan fragmen gen COI sepanjang 570 bp dengan suhu optimal PCR sebesar $56,5{ }^{\circ} \mathrm{C}$. Prosentase basa $\mathrm{G}+\mathrm{C}$ dalam desain primer forward - reverse ini sebesar 50\% dan 55\%, dimana prosentase ini sudah sangat baik karena telah memenuhi syarat prosentase $\mathrm{G}+\mathrm{C}$ untuk keberhasilan PCR sebesar 50-60\% (Yuwono, 2009).

\section{KESIMPULAN}

Penelitian yang telah dilakukan memperoleh kesimpulan bahwa ketiga pasang primer yang digunakan yaitu primer HCO-LCO, primer bird-f1 - HCO, dan primer bch-bcl tidak dapat digunakan 
untuk mengamplifikasi gen COI DNA mitokondria itik Magelang (Anas javanica).

\section{UCAPAN TERIMA KASIH}

Peneliti mengucapkan terima kasih kepada Tim Peneliti Hersugondo, Hermin Pancasakti Kusumaningrum dan Muhammad Zainuri, karena telah memberikan kesempatan untuk ikut dalam proyek Hibah Ibm Dirjen DIKTI Kementerian Pendidikan Nasional tahun 2010 dengan judul Pemanfaatan Limbah Kerang Simping, Cangkang Kepiting, Wideng dan Ikan Rucah untuk Pengkaya Pakan Guna Meningkatkan Produksi dan Kualitas telur, Derajat Kesehatan itik dan Pendapatan Peternak Itik Kota Tegal untuk membantu penelitian yang telah peneliti lakukan.

\section{DAFTAR PUSTAKA}

Ahanthem,M. and S.K. Ghosh. 2011. DNA barcoding of domestic fowls from Northeast India, Submitted (27-SEP-2011) Biotechnology, Assam University (CentralUniversity), Durgakona, Silchar, Assam 788011, India.

Aussubel, F.M., R. Brent, R.E. Kingston, D. D. Moore, J. G. Seidman, J. J. Smith, and K. Struhl. 1995. Current protocol in moleculer biology Volume I. John Willey and Sons. Canada.

Bondoc, O. L. 2012. Genetic Diversity and Relationship of Common Poultry Breeds and Strains (Class Aves) in the Philippines Based on the Cytochrome C Oxidase I (COI) Gene Sequence, Submitted (08-JUN-2012) Animal and Dairy Sciences Cluster, College of Agriculture, University of the Philppines
Los Banos, ADSC, CA, UPLB, Los Banos, Laguna 4030, Philippines.

Dinas Peternakan dan Kesehatan Hewan Jawa Tengah. 2010. Populasi Ternak Unggas Jawa Tengah 2010.

Sambrook, J., Fritsch, and T. Maniatis. 2001. Molecular Cloning. A Laboratory Manual.Second edition.Cold Spring Harbor Laboratory Press.

Subandriyo. 2006.Konservasi Sumberdaya Genetik Ternak: Pertimbangan, Kriteria, Metoda dan Strategi. dalam Lokakarya Nasional Pengelolaan dan Perlindungan Sumber Daya Genetik di Indonesia: Manfaat Ekonomi untuk Mewujudkan Ketahanan Nasional. Pusat Penelitian dan Pengembangan Peternakan. Bogor.

Sudjito, Y.L. 2012.Isolasi DNA Kerang Simping (Amusium pleuronectes) Dengan Modifikasi Tahap Lisis Sel. Kerja Praktik. Program Studi Biologi, FSM Universitas Diponegoro. Semarang.

Sulistyaningsih.2008. Identifikasi Isolat Bakteri Penghasil Zat Antibakteri dari Cairan Kantung Tanaman Kantung Semar (Nepenthes ampullaria Jack).Laporan Penelitian Mandiri. Universitas Padjadjaran. Bandung.

Wibowo, S.E. 2012. Pelacakan Gen Sitokrom Oksidase Sub Unit I (COI) DNA Mitokondria Itik Tegal (Anas domesticus) Menggunakan Primer Universal. Skripsi. Program Studi Biologi, FSM Universitas Diponegoro. Semarang.

Yuwono, T. 2009. Teori dan Aplikasi Polymerase Chain Reaction. Penerbit Andi, Yogyakarta. 